\title{
Spatial and temporal occurrence of killer whale ecotypes off the outer coast of Washington State, USA
}

\author{
Ally Rice ${ }^{1, *}$, Volker B. Deecke ${ }^{2}$, John K. B. Ford ${ }^{3}$, James F. Pilkington ${ }^{3}$, \\ Erin M. Oleson ${ }^{4}$, John A. Hildebrand ${ }^{1}$, Ana Širović ${ }^{1}$ \\ ${ }^{1}$ Scripps Institution of Oceanography, University of California, San Diego, La Jolla, California 92037, USA \\ ${ }^{2}$ Centre for Wildlife Conservation, University of Cumbria, Ambleside, LA22 9BB, Cumbria, UK \\ ${ }^{3}$ Pacific Biological Station, Fisheries and Oceans Canada, Nanaimo, British Columbia V9T 6N7, Canada \\ ${ }^{4}$ Pacific Islands Fisheries Science Center, National Oceanic and Atmospheric Administration, Honolulu, Hawaii 96818, USA
}

\begin{abstract}
Three killer whale Orcinus orca ecotypes inhabit the northeastern Pacific: residents, transients, and offshores. To investigate intraspecific differences in spatial and temporal occurrence off the outer coast of Washington State, USA, 2 long-term acoustic recorders were deployed from July 2004 to August 2013: one off the continental shelf in Quinault Canyon (QC) and the other on the shelf, off Cape Elizabeth (CE). Acoustic encounters containing pulsed calls were analyzed for call types attributable to specific ecotypes, as no calls are shared between ecotypes. Both sites showed killer whale presence year-round, although site CE had a higher number of days with encounters overall. Transients were the most common ecotype at both sites and were encountered mainly during the spring and early summer. Residents were encountered primarily at site CE and showed potential seasonal segregation between the 2 resident communities, with northern residents present mainly during summer and early fall when southern residents were not encountered. Offshore encounters were higher at site QC, with little evidence for seasonality. Spatial and temporal variability of residents and transients matches the distribution of their prey and can potentially be used for further inferences about prey preferences for different transient groups.
\end{abstract}

KEY WORDS: Orcinus orca - Seasonality - Prey preferences - Passive acoustic monitoring · Northeastern Pacific

\section{INTRODUCTION}

Three distinct killer whale Orcinus orca ecotypes have been identified in the northeastern Pacific: resident, transient, and offshore. These ecotypes differ morphologically, genetically, behaviorally, and acoustically (Bigg et al. 1990, Ford 1991, Ford et al. 1998, Hoelzel et al. 1998, Barrett-Lennard 2000, Deecke et al. 2005, Dahlheim et al. 2008). Residents have been the focus of numerous studies and therefore their social structure, prey preferences, and acoustic behaviors are relatively well understood (Ford 1989, Bigg et al. 1990, Ford et al. 1998, Ford \& Ellis 2006). Less is known about the marine mammal-hunting transients (also

\footnotetext{
${ }^{*}$ Corresponding author: ally.c.rice@gmail.com
}

known as Bigg's killer whales), and considerably less is known about offshores (Bigg et al. 1990, Ford et al. 2011). Off Washington State (USA), killer whales are an apex predator in a highly productive ecosystem, but currently there is only limited knowledge of the different ecotypes' spatial and seasonal presence in this region.

Killer whales produce 3 main types of vocalizations: clicks, whistles (which can be further subdivided into low frequency and ultrasonic), and pulsed calls (Ford 1989, Thomsen et al. 2001, Samarra et al. 2010, Simonis et al. 2012). Clicks are short pulses that typically occur in a series and are used for echolocation, while whistles consist of a single tone that typically contains

() A. Rice, V. Deecke, J. Hidebrand, A. Sirovic, Fisheries and Oceans Canada, U.S. Government 2017. Open Access under Creative Commons by Attribution Licence. Use, distribution and reproduction are unrestricted. Authors and original publication must be credited.

Publisher: Inter-Research · www.int-res.com 
modulations and shifts in frequency (Ford 1989). Pulsed calls are characterized by a high repetition rate of sound pulses that result in calls that sound tonal to the human ear (Ford 1989). Pulsed calls generally have a peak energy between 1 and $6 \mathrm{kHz}$ and are usually 0.5 to $1.5 \mathrm{~s}$ in duration (Ford 1989).

Each ecotype has a unique repertoire of pulsed calls that can serve as acoustic indicators of presence (Ford 1991, Barrett-Lennard et al. 1996, Deecke et al. 2005). Vocal rates also differ between ecotypes, with transients vocalizing significantly less often due to the audibility of their calls to marine mammal prey (Barrett-Lennard et al. 1996, Deecke et al. 2005).

There is also repertoire variation within some ecotypes, often making it possible to identify a specific community or even matriline based on calls (Ford 1991, Deecke 2003). The resident ecotype in the study area is composed of 2 communities, northern residents and southern residents, which do not share any call types and can therefore be easily differentiated. Transients found in this region are a part of the west coast transient (WCT) population, ranging from southern Alaska to California. Knowledge of transient social structure is still limited, but this population is thought to be composed of multiple groups that are generally referred to by the geographic location in which they are typically sighted; either around southeast Alaska and British Columbia, or off California (Deecke 2003). However, the ranges of these groups overlap considerably, and therefore delineating transient groups geographically may not be practical (Goley \& Straley 1994, Black et al. 2002, Deecke 2003). While there is some call type overlap across the WCT population, it is possible to acoustically distinguish between different transient groups (Deecke 2003). Using previously reported call types (Deecke 2003), and ignoring recording location, it is possible to divide the WCT population into 3 distinct dialect groups (labeled A, B, and C in Table 1), based on which calls are typically recorded together during a given encounter. Dialect groups A and B are made up of calls that have typically been recorded in southeast Alaska and British Columbia, while dialect group C consists of calls mainly recorded off California. These transient dialects are not as pronounced as in the resident ecotype (Ford 1991). Paucity of data on offshore killer whale acoustics and social structure currently makes it impossible to determine whether smaller-scale groups can be identified acoustically. Acoustic variation between the ecotypes, however, makes passive acoustic monitoring a useful method for assessing intraspecific differences.
Table 1. Delineation of west coast transient (WCT) dialect groups of killer whales Orcinus orca based on the call types they produce

\begin{tabular}{|lcccc|}
\hline \multirow{2}{*}{ Call type } & \multicolumn{4}{c}{ Dialect group } \\
\cline { 2 - 5 } & $\mathrm{A}$ & $\mathrm{B}$ & $\mathrm{C}$ & $\mathrm{D}$ \\
\hline WCT01 & $\mathrm{X}$ & $\mathrm{X}$ & $\mathrm{X}$ & $\mathrm{X}$ \\
WCT02i & $\mathrm{X}$ & & $\mathrm{X}$ & $\mathrm{X}$ \\
WCT02iii & & $\mathrm{X}$ & & \\
WCT03 & $\mathrm{X}$ & & & \\
WCT04 & & $\mathrm{X}$ & & \\
WCT07 & $\mathrm{X}$ & & & \\
WCT08 & $\mathrm{X}$ & $\mathrm{X}$ & $\mathrm{X}$ & $\mathrm{X}$ \\
WCT09 & & & $\mathrm{X}$ & $\mathrm{X}$ \\
WCT10 & & & $\mathrm{X}$ & $\mathrm{X}$ \\
WCT11 & $\mathrm{X}$ & $\mathrm{X}$ & $\mathrm{X}$ & $\mathrm{X}$ \\
WCT12i & & & $\mathrm{X}$ & \\
WCT12ii & & & $\mathrm{X}$ & $\mathrm{X}$ \\
WCT13 & $\mathrm{X}$ & $\mathrm{X}$ & $\mathrm{X}$ & $\mathrm{X}$ \\
WCT14 & & & $\mathrm{X}$ & $\mathrm{X}$ \\
WCT15 & & & & \\
\hline
\end{tabular}

Although numerous differences exist among the killer whale ecotypes in the Northeastern Pacific, they are all facing similar threats, such as bioaccumulating compounds and noise pollution due to increased boat traffic (Nehlsen et al. 1991, Ross et al. 2000, Erbe 2002, Rayne et al. 2004). Additionally, residents are threatened by the decline in salmon (Oncorhynchus spp.) stocks, which has been occurring since the 1850s (Nehlsen et al. 1991, Ford et al. 2010), and the southern resident community is currently listed as endangered in the USA and Canada under the US Endangered Species Act and the Species at Risk Act, respectively.

Effective designation of critical habitat for these atrisk groups must account for seasonal variation in habitat use. Visual surveys off Washington have confirmed year-round killer whale presence in the area, but sightings are infrequent, making it difficult to establish long-term spatial or temporal trends (Calambokidis et al. 2004, Hanson et al. 2008a,b, 2009, 2010, Oleson et al. 2009, 2012). Acoustic detections of each of the 3 ecotypes have been reported off Vancouver Island and Washington State (Riera 2012). Southern residents spend time off the coast of Washington during the winter, suggesting that Columbia River Chinook salmon $O$. tshawytscha may represent an important prey source for this community (Hanson et al. 2013). However, long-term patterns of all killer whale ecotypes' presence in this area is unknown, yet a better understanding of these apex predators, and their relationship to their prey, is necessary to effectively manage and conserve the ecosystem of this 
region. For this study, we analyzed passive acoustic data collected over a $10 \mathrm{yr}$ period to provide a longterm view of the spatial and temporal habitat use of the different killer whale ecotypes off the outer coast of Washington.

\section{MATERIALS AND METHODS}

\section{Study area}

Passive acoustic monitoring was conducted at 2 sites off the outer coast of Washington using high-frequency acoustic recording packages (HARPs; Wiggins \& Hildebrand 2007; Fig. 1). One site was located at the shelf slope near Quinault Canyon (site QC), about $75 \mathrm{~km}$ from shore. This site was monitored intermittently from October 2004 to June 2013 (Fig. 2). The second site was located on the continental shelf off Cape Elizabeth (site CE), about $35 \mathrm{~km}$ from shore and within the Olympic Coast National Marine Sanctuary, a highly productive marine environment. This site was monitored intermittently from July 2004 to August 2013 (Fig. 2).

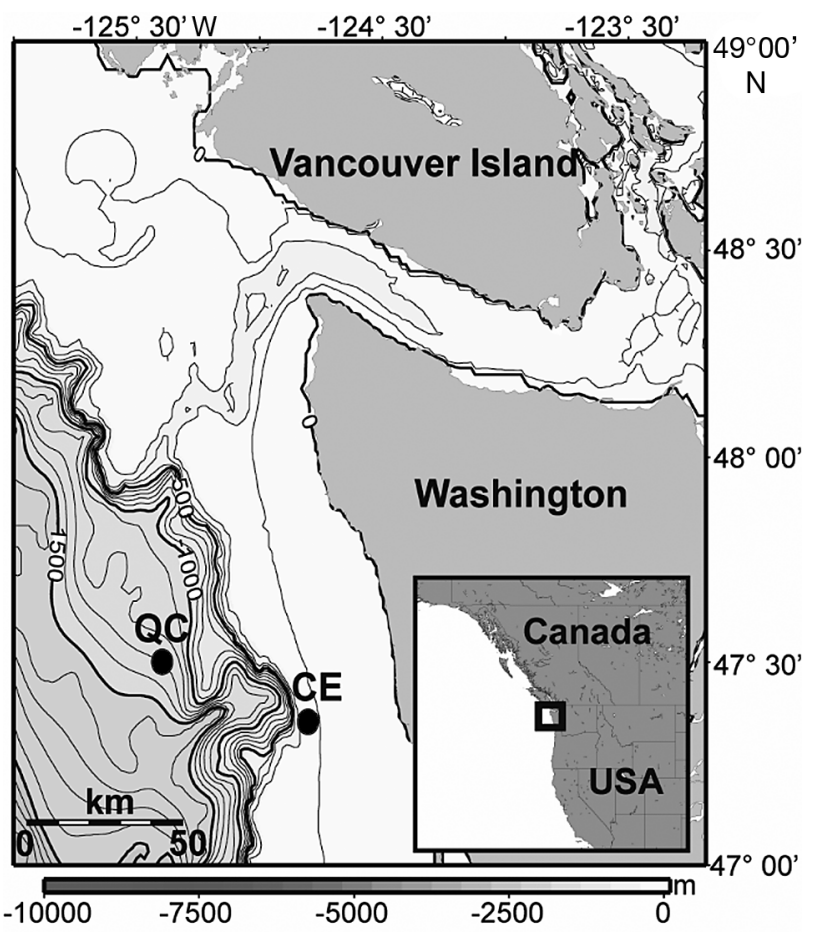

Fig. 1. Coastal waters of Washington State (USA), showing the locations of high-frequency acoustic recording package deployments from July 2004 to August 2013. Grayscale shows bathymetric depth in meters; CE: Cape Elizabeth, QC: Quinault Canyon sites

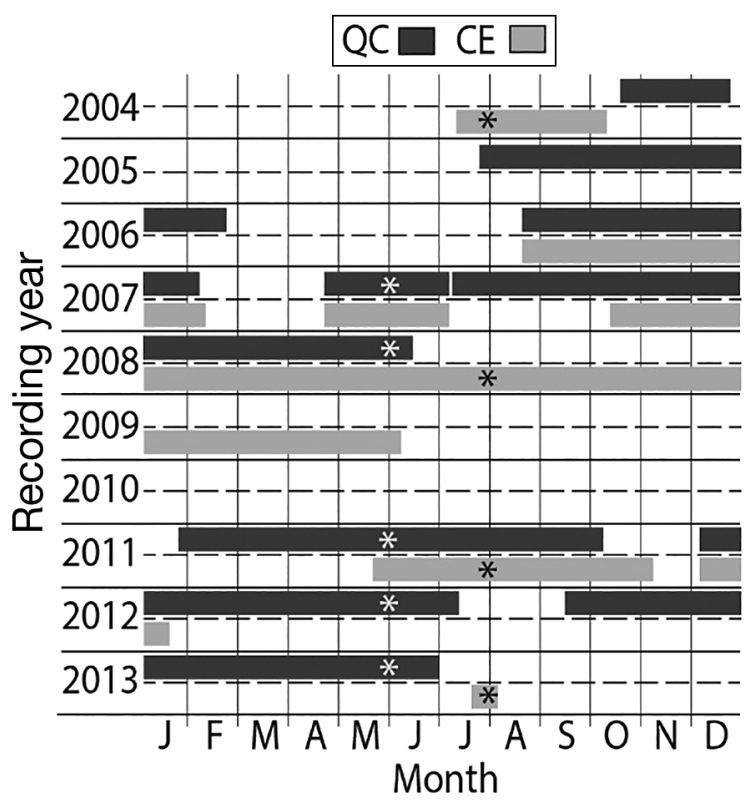

Fig. 2. Monthly recording effort used for analysis of killer whale Orcinus orca acoustic presence each year is shown as horizontal bars for Quinault Canyon (QC) and Cape Elizabeth (CE). Deployments containing data used to examine interannual trends at each site are indicated with an asterisk. Some deployments from 2004-2009 were duty cycled (see Table 2)

\section{Data collection and analysis}

HARPs were placed on the seafloor with a calibrated hydrophone suspended about $20 \mathrm{~m}$ above (Wiggins \& Hildebrand 2007). They recorded at an $80 \mathrm{kHz}$ sampling frequency for deployments from 2004 to 2007 and at a $200 \mathrm{kHz}$ sampling frequency for later deployments (Table 2). All but 7 deployments had continuous recording (Table 2). Before analysis, data were decimated to a $10 \mathrm{kHz}$ sampling frequency, allowing more effective scanning up to $5 \mathrm{kHz}$. Longterm spectral averages (LTSAs) were created using a $5 \mathrm{~s}$ time average and a $10 \mathrm{~Hz}$ frequency resolution and were scanned by an analyst for killer whale whistles and pulsed calls. When a potential killer whale signal was identified in the LTSA, a $30 \mathrm{~s}$ long spectrogram (1000 Fast Fourier Transform length, 65\% overlap) was examined to confirm species identity. Calls were logged as encounters, where encounters were considered independent if they were both preceded and succeeded by at least 15 min of recording that did not contain any calls. For deployments with duty cycled data, the periods without recording were counted towards this $15 \mathrm{~min}$ period, since there was no way to verify if the animals had continued calling during the gap. Only encounters containing pulsed calls were used for further analysis. 
Table 2. Details on high-frequency acoustic recording package deployments including site, latitude, longitude, depth, duty cycle (on/off duration, each in min, with 0/0 denoting continuous recording), sampling frequency, and time periods analyzed for this study. CE: Cape Elizabeth, QC: Quinault Canyon; dates are given as mm/dd/yyyy

\begin{tabular}{|c|c|c|c|c|c|c|c|}
\hline Site & Latitude (N) & Longitude (W) & $\begin{array}{l}\text { Depth } \\
\text { (m) }\end{array}$ & $\begin{array}{l}\text { Duty cycle } \\
\text { (min) }\end{array}$ & $\begin{array}{l}\text { Sample frequency } \\
(\mathrm{kHz})\end{array}$ & Data start & Data end \\
\hline \multirow[t]{8}{*}{$\mathrm{CE}$} & $47^{\circ} 21.80^{\prime}$ & $124^{\circ} 45.39^{\prime}$ & 150 & $0 / 0$ & 80 & $7 / 12 / 2004$ & $10 / 5 / 2004$ \\
\hline & $47^{\circ} 21.70^{\prime}$ & $124^{\circ} 42.08^{\prime}$ & 150 & $6 / 12$ & 80 & $8 / 18 / 2006$ & $2 / 13 / 2007$ \\
\hline & $47^{\circ} 21.62^{\prime}$ & $124^{\circ} 42.09^{\prime}$ & 100 & $0 / 0$ & 80 & $4 / 21 / 2007$ & $7 / 3 / 2007$ \\
\hline & $47^{\circ} 21.49^{\prime}$ & $124^{\circ} 40.99^{\prime}$ & 150 & $5 / 23$ & 200 & $10 / 14 / 2007$ & $6 / 16 / 2008$ \\
\hline & $47^{\circ} 21.48^{\prime}$ & $124^{\circ} 41.00^{\prime}$ & 100 & $5 / 30$ & 200 & $6 / 17 / 2008$ & $6 / 9 / 2009$ \\
\hline & $47^{\circ} 21.12^{\prime}$ & $124^{\circ} 43.26^{\prime}$ & 118 & $0 / 0$ & 200 & $5 / 21 / 2011$ & $11 / 6 / 2011$ \\
\hline & $47^{\circ} 21.14^{\prime}$ & $124^{\circ} 43.28^{\prime}$ & 150 & $0 / 0$ & 200 & $12 / 7 / 2011$ & $1 / 17 / 2012$ \\
\hline & $47^{\circ} 21.17^{\prime}$ & $124^{\circ} 42.47^{\prime}$ & 120 & $0 / 0$ & 200 & $7 / 17 / 2013$ & $8 / 04 / 2013$ \\
\hline \multirow[t]{8}{*}{$\mathrm{QC}$} & $47^{\circ} 27.63^{\prime}$ & $125^{\circ} 07.88^{\prime}$ & 915 & $10.25 / 19.75$ & 80 & $10 / 19 / 2004$ & $12 / 21 / 2004$ \\
\hline & $47^{\circ} 28.05^{\prime}$ & $125^{\circ} 09.17^{\prime}$ & 823 & $6 / 12$ & 80 & $7 / 28 / 2005$ & $2 / 20 / 2006$ \\
\hline & $47^{\circ} 28.13^{\prime}$ & $125^{\circ} 09.80^{\prime}$ & 615 & $6 / 12$ & 80 & $8 / 18 / 2006$ & $2 / 7 / 2007$ \\
\hline & $47^{\circ} 27.97^{\prime}$ & $125^{\circ} 09.21^{\prime}$ & 620 & $0 / 0$ & 80 & $4 / 21 / 2007$ & $7 / 3 / 2007$ \\
\hline & $47^{\circ} 27.96^{\prime}$ & $125^{\circ} 09.20^{\prime}$ & 653 & $5 / 30$ & 200 & $7 / 5 / 2007$ & $6 / 15 / 2008$ \\
\hline & $47^{\circ} 30.00^{\prime}$ & $125^{\circ} 21.20^{\prime}$ & 650 & $0 / 0$ & 200 & $1 / 27 / 2011$ & $10 / 7 / 2011$ \\
\hline & $47^{\circ} 30.03^{\prime}$ & $125^{\circ} 21.21^{\prime}$ & 1394 & $0 / 0$ & 200 & $12 / 7 / 2011$ & $7 / 11 / 2012$ \\
\hline & $47^{\circ} 30.03^{\prime}$ & $125^{\circ} 21.22^{\prime}$ & 1394 & $0 / 0$ & 200 & $9 / 14 / 2012$ & $6 / 30 / 2013$ \\
\hline
\end{tabular}

\section{Ecotype identification}

The pulsed calls in each encounter were viewed in a $10 \mathrm{~s}$ long spectrogram window in order to visually and aurally identify call types that could be used to distinguish between ecotypes. Each call in an encounter was examined before the encounter was attributed to an ecotype and community or group. In some cases, calls from both resident communities or multiple transient dialect groups were present in 1 encounter. If calls from both southern and northern residents were present in a single encounter, for example, the encounter was treated as both a southern resident encounter and a northern resident encounter in further analysis.

Resident killer whale calls were identified using the reference catalogue published by Ford (1987). Residents were identified as southern resident or northern resident, with further identification to clans and pods when possible. For a description of resident clans and pods see Bigg et al. (1990) and Ford (1991).

Transients have previously been broken into groups based on sighting and recording location (Deecke 2003). However, for the purposes of this study, transients were identified according to dialect group, not location. Dialect groups A, B, and C were established using a digitized catalogue of call types and subtypes made from recordings analyzed by Deecke (2003). During the initial classification of encounters, a previously unclassified transient call type was discovered. We found no encounters with the previously recorded WCT12 call type (Deecke 2003), but instead found many instances of other dialect group $\mathrm{C}$ call types produced with what appeared to be a variant of the WCT12 call type, which we refer to as WCT12ii (the original WCT12 call now being referred to as WCT12i; Fig. 3). There are visual differences apparent in the spectrograms of these 2 call types, particularly in the high frequency component of the call, as well as in the overall structure and duration (Fig. 3). However, we have chosen to classify them as variants of the same call type due to shared aural features. To account for this in our analysis, we defined a fourth transient dialect group, $\mathrm{D}$, as a dialect consisting of many of the same call types as group $\mathrm{C}$, but with WCT12ii instead of WCT12i (Table 1). Since there are shared call types between the dialect groups, only call types unique to a single dialect group were used to assign encounters to a transient dialect group. When an encounter could not be attributed with certainty to a dialect group (for example, because it only included call types shared by all WCTs), it was classified as an unidentified transient.

Offshore encounters were confirmed by 2 of the authors (J.K.B.F. and J.F.P.) using a digital catalog of offshore call types (J. Ford unpubl. data) collected during field encounters with photo- or genetically identified offshore killer whales.

Encounters that could not be identified to the ecotype level were labeled 'unidentified'. Unidentified encounters were typically short in duration and contained short and faint calls that were not sufficient for 


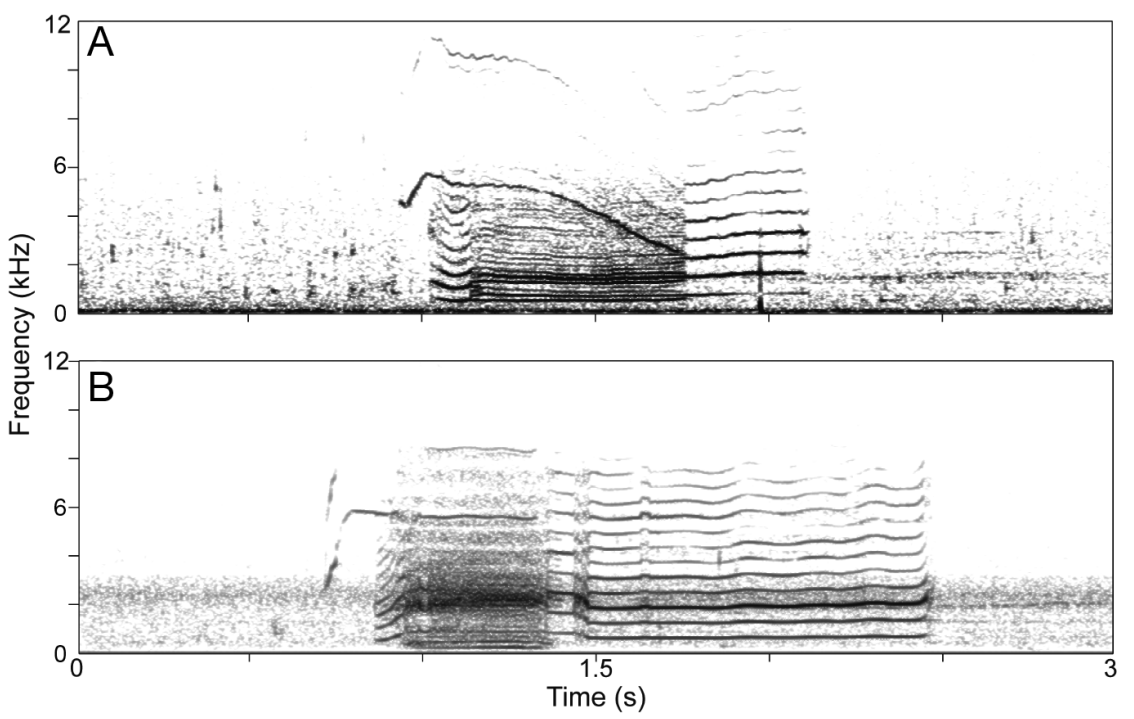

Fig. 3. Example spectrograms (Hanning window, 3 s analysis window, $90 \%$ overlap) of (A) the previously documented WCT12i killer whale Orcinus orca call type recorded off California, USA (Deecke 2003), and (B) the newly classified WCT12ii call type (example shown was recorded in British Columbia, Canada; J. Ford unpubl. data)

making ecotype identifications. Classifications for all ecotypes were verified by multiple analysts. If there was any uncertainty about the classification for an encounter, it was labeled unidentified.

\section{Statistical analysis}

Killer whale acoustic encounters are reported as the number of days with encounters relative to the number of days of effort during the year, month, or season analyzed. Acoustic encounters were not normally distributed, so nonparametric tests were chosen for statistical analysis. A Wilcoxon rank sum test was used to examine whether the number of days with encounters was significantly higher at either site. Since recording periods were intermittent (Fig. 2), only concurrent recording periods for the 2 sites were used for this analysis to avoid sampling bias due to seasonal variation in effort. Five time periods were selected: 3 from August 2006 to June 2008 and 2 from May 2011 to January 2012. A Mann-Kendall monotonic trend test (at $\alpha=0.05$ ) was used to test whether there was an interannual trend in the data. Interannual trends were analyzed from a subset of data, using a time period when overall killer whale acoustic encounters were typically highest at each site. This subset was selected to remove any bias resulting from variations in timing of effort across years of the study (Fig. 2). For site QC we used detections from May to June (data during those months were available for 2007, 2008, 2011, 2012, and 2013), and for site CE we used detections from July to August (data from 2004, 2008, 2011, and 2013; Fig. 2). These time periods were chosen because they were generally times with many encounters, and also had coverage in the greatest number of years. Diel trends were examined by plotting encounters along with sunrise and sunset times for each site. These plots allowed for easy visual comparison of daytime and nighttime encounters. To look at seasonal variation for the different ecotypes at each site, we used a Kruskal-Wallis test. Post hoc multiple comparisons between seasons were performed using a Dunn's test with Benjamini-Hochberg corrected alpha levels of 0.025 . For examining seasonal variation, we defined seasons as winter: December, January, February; spring: March, April, May; summer: June, July, August; fall: September, October, November. Sample sizes varied for each season at each site $(Q C, C E)$ : winter $(n=18,11)$, spring $(n=14,10)$, summer $(\mathrm{n}=13,14)$, and fall $(16,13)$.

\section{RESULTS}

\section{Spatial and temporal distribution of encounters}

There were 443 killer whale encounters throughout the study period. These encounters resulted in $133.3 \mathrm{~h}$ of calling over $204 \mathrm{~d}$. Site QC had 110 total encounters over $69 \mathrm{~d}$, while site CE had 333 total encounters over $147 \mathrm{~d}$ (there were $12 \mathrm{~d}$ when calls were recorded at both sites). There were $42 \mathrm{~d}$ with resident encounters ( 3 at $\mathrm{QC}$ and 39 at $\mathrm{CE}$ ), $121 \mathrm{~d}$ with transient encounters ( 34 at $\mathrm{QC}$ and 87 at $\mathrm{CE}$ ), and $23 \mathrm{~d}$ with offshore encounters (15 at QC and 8 at $\mathrm{CE})$ overall.

Recording effort differed between sites, with $1630 \mathrm{~d}$ with effort at site QC and $1202 \mathrm{~d}$ at CE. Site $\mathrm{CE}$ had a higher percentage of days with killer whale acoustic presence $(12.2 \%)$ than site QC $(4.2 \%)$, but the number of days with encounters was not significantly higher at site $\mathrm{CE}$ for periods where recording overlapped at both sites (Wilcoxon rank sum: $\mathrm{n}=5$, rank sum $=20.5, p=0.183$ ). As far as spatial distribution of ecotypes is concerned, there were more days with resident encounters at site CE $(26.5 \%)$ than site 
QC $(4.3 \%)$, although this difference was not significant (Wilcoxon rank sum: $\mathrm{n}=5$, rank sum $=20, \mathrm{p}=0.167$ ). There was a significant difference in transient encounters, with more days with encounters at site CE (Wilcoxon rank sum: $\mathrm{n}=5$, rank sum $=18, \mathrm{p}=$ $0.04)$. There were more days with offshore encounters at site QC $(21.7 \%$ of days compared to only $5.4 \%$ at site $\mathrm{CE}$ ), although the difference for offshores was not significant (Wilcoxon rank sum: $\mathrm{n}=5$, rank sum $=30, \mathrm{p}=$ $0.714)$. It was not possible to identify the ecotype on $28.9 \%$ of days with killer whale call encounters. These unidentified encounters were more com-

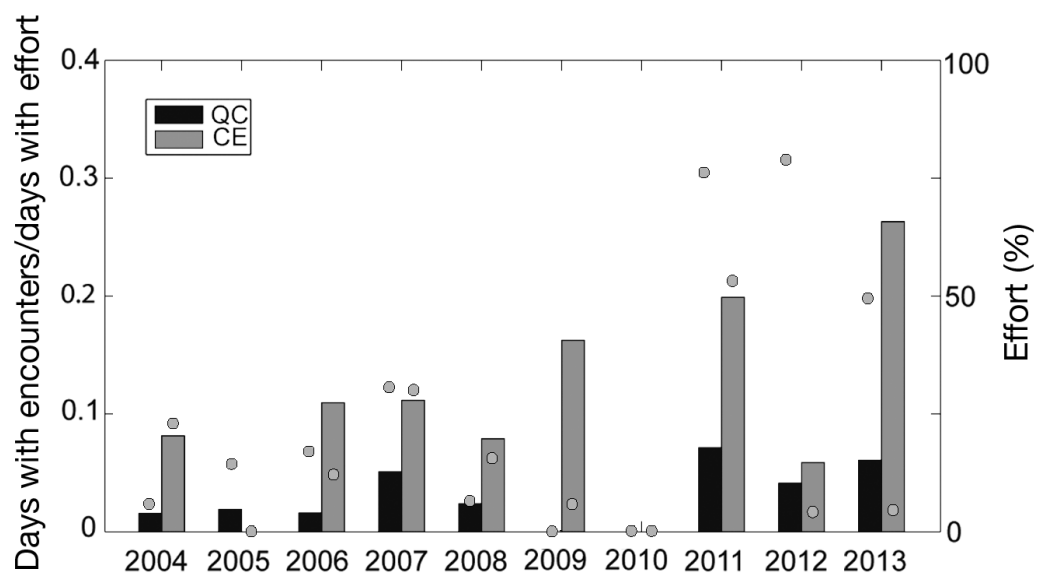

Fig. 4. Yearly proportion of days with killer whale Orcinus orca acoustic encounters standardized for recording effort at each site (CE: Cape Elizabeth, QC: Quinault Canyon). Gray dots show the percentage of the days in a year that had recording effort mon at site $\mathrm{QC}$, relative to the other ecotypes, with $43.5 \%$ of days having unidentified encounters at QC and only $19.7 \%$ of days at CE, although the difference was not significant (Wilcoxon rank sum: $\mathrm{n}=5$, rank sum $=25, \mathrm{p}=0.691$ ). There were no interannual trends at either site $\mathrm{QC}$ or $\mathrm{CE}$

overall (Mann-Kendall: $\mathrm{n}=5, \mathrm{p}=1$; and $\mathrm{n}=4, \mathrm{p}=$ 0.425 , respectively; Fig. 4). Additionally, there were no obvious diel trends for any of the ecotypes.

There was seasonal variation in the number of days with resident and transient encounters. Resident en-

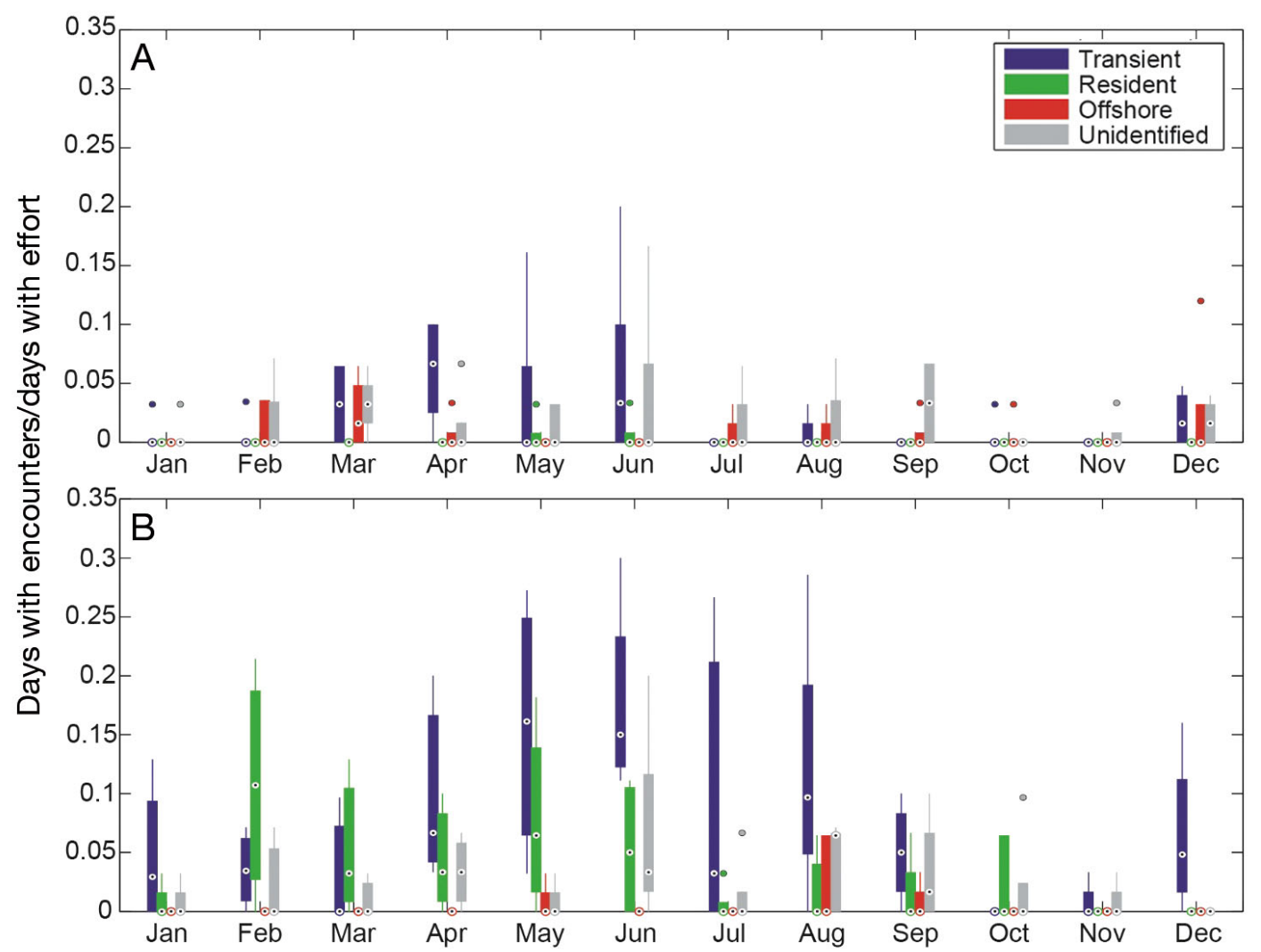

Fig. 5. Proportion of days with killer whale Orcinus orca acoustic encounters, standardized for effort, for each month at (A) Quinault Canyon and (B) Cape Elizabeth for each ecotype. Circled dots indicate the median, and the bottom and top edges of each box represent the lower (25\%) and upper (75\%) quartiles, respectively. Whiskers show maximum and minimum values, and solid dots represent outliers 
counters occurred primarily in May and June at site QC (Fig. 5A), although site QC had few resident encounters overall. At site $C E$, resident encounters occurred during most months but were most common from February to June (Fig. 5B). Overall, there was no significant seasonal difference in the number of days with resident encounters at either site (KruskalWallis: $H=2.57, \mathrm{p}=0.462$ and $H=5.83, \mathrm{p}=0.12$ for sites QC and CE, respectively; Fig. 6). Transients were encountered mainly from March to June at site QC (Fig. 5A) and from December to August at site CE (Fig. 5B). Both sites showed a significant seasonal difference in the number of days with transient encoun-

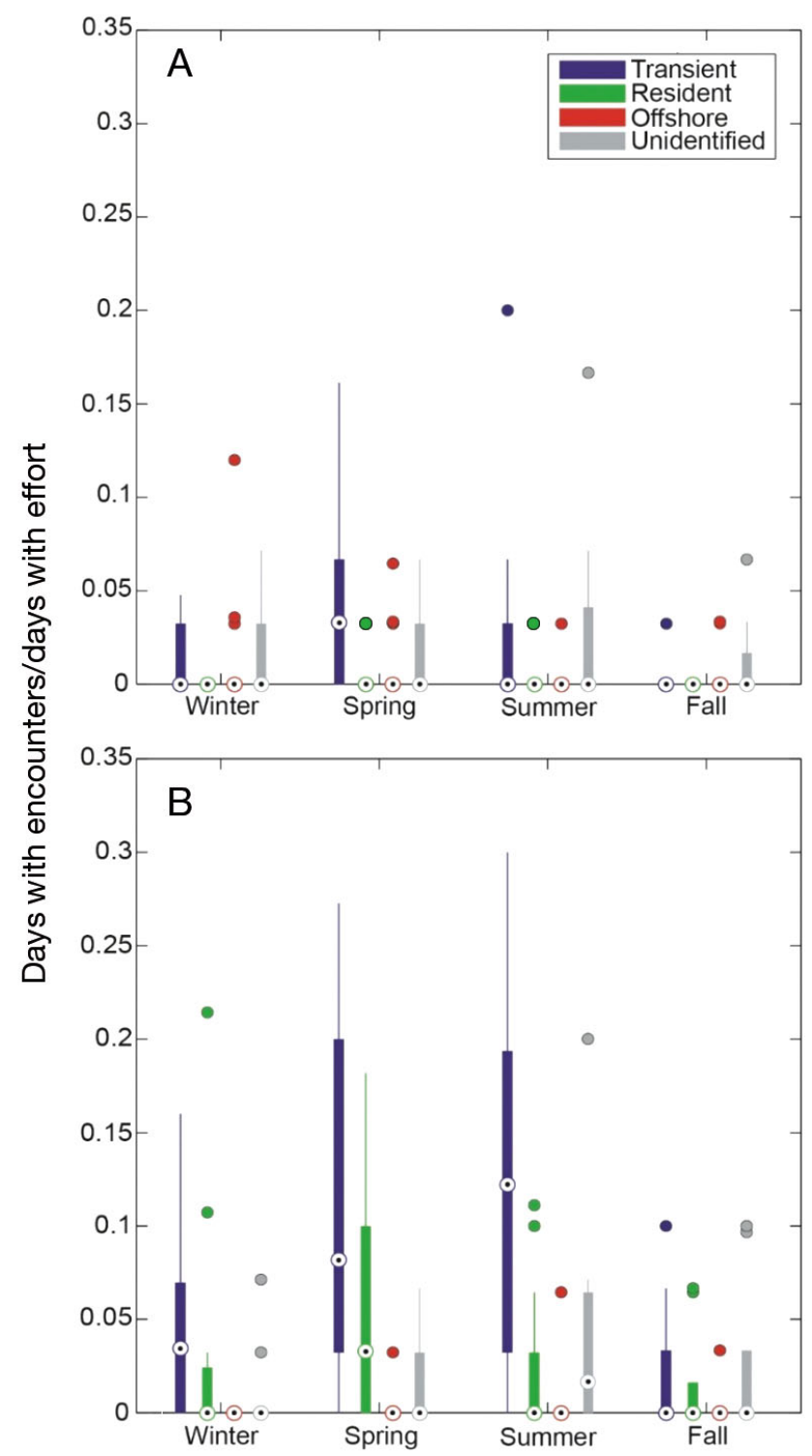

Fig. 6. Proportion of days with killer whale Orcinus orca acoustic encounters, standardized for effort, for each season at (A) Quinault Canyon and (B) Cape Elizabeth. Box plot details as in Fig. 5 ters (Kruskal-Wallis: $H=11.04, \mathrm{p}=0.012$ and $H=$ $11.75, \mathrm{p}=0.008$ for sites $\mathrm{QC}$ and $\mathrm{CE}$, respectively; Fig. 6). Offshores were encountered during most months at site QC (Fig. 5A) but only during May, August, and September at site CE (Fig. 5B). Overall, no significant seasonal pattern was recognized for offshores at either site (Kruskal-Wallis: $H=1.02, \mathrm{p}=$ 0.798 and $H=1.77, \mathrm{p}=0.622$ for sites $\mathrm{QC}$ and $\mathrm{CE}$, respectively; Fig. 6). Unidentified killer whales were encountered in most months at both sites (Fig. 5), with no seasonal variation (Kruskal-Wallis: $H=0.52$, $\mathrm{p}=0.914$ and $H=3.24, \mathrm{p}=0.356$ for sites $\mathrm{QC}$ and $\mathrm{CE}$, respectively; Fig. 6).

\section{Resident clans and pods}

All 4 resident encounters at site QC were southern residents, specifically $\mathrm{J}$ pod. At site $\mathrm{CE}$, both the southern and northern resident communities were encountered. All 3 southern resident pods were encountered at site CE, with L (10.2\%) and K (8.8\%) pod encounters occurring on more days than $\mathrm{J}$ pod $(5.4 \%)$. Southern residents were detected mainly from February to June and were absent from July to September, when northern residents from A and G clans were encountered (Fig. 7). Northern resident encounters also occurred in February (both A and G clans) and in October (only G clan). There was 1 encounter in February at site CE when both communities were present (G clan and L pod). We found significantly more days with southern resident encounters at site $C E$ in the spring than in the summer and fall (Dunn's test: $Z=2.81, \mathrm{p}=0.007$ and $Z=2.88, \mathrm{p}=$ 0.012 , respectively; Table 3 ).

\section{Transient dialect groups}

A previously unclassified transient call type was identified during this study. Transient groups were identified using acoustic dialects and, based on the discovery of a previously unclassified transient call type, a fourth dialect group (D) was added when classifying transient encounters (Table 1). Transient dialect groups A, B, and D were detected at both sites. There were no encounters of dialect group $\mathrm{C}$ at either site. Each site occasionally had acoustic encounters with individuals from $>1$ dialect group, and on 3 separate days all 3 groups were present in the same encounter. While each transient dialect group had a higher number of days with encounters at site $\mathrm{CE}$, this difference was only significant for dialect 


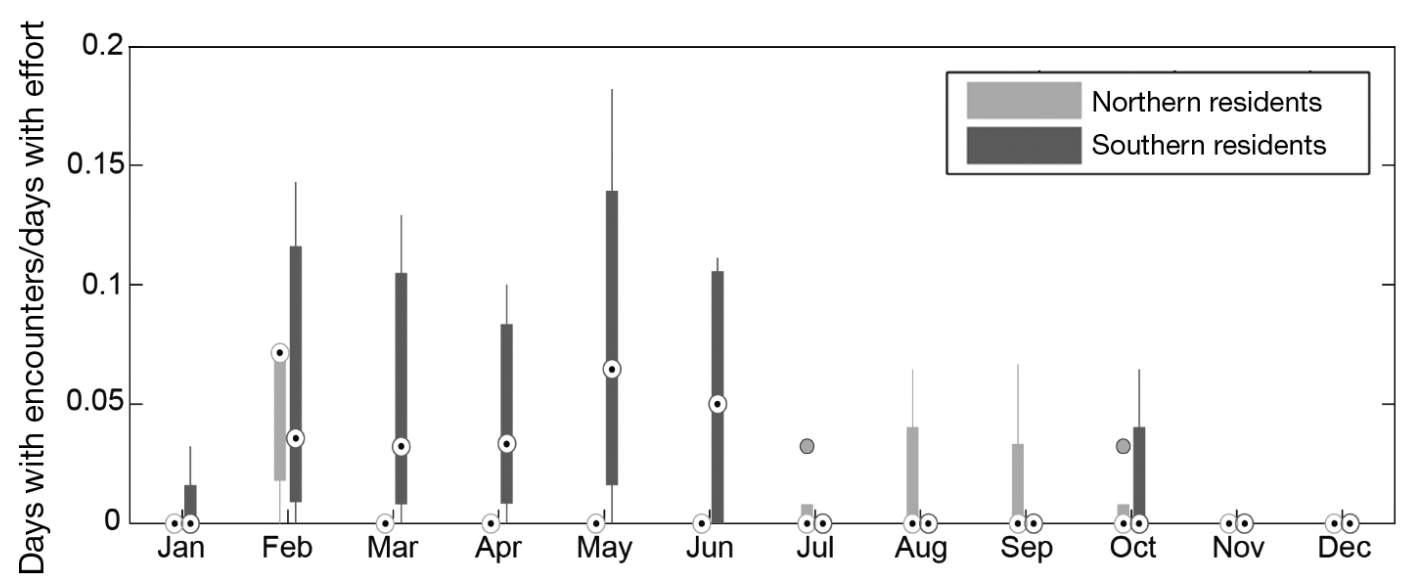

Fig. 7. Proportion of days with resident killer whale Orcinus orca acoustic encounters, standardized for effort, for each month for the 2 resident communities at Cape Elizabeth. Box plot details as in Fig. 5

Table 3. Pairwise comparison of seasonal variability for killer whale Orcinus orca southern residents and transient dialect group A. Sample sizes varied at each site (CE: Cape Elizabeth, QC: Quinault Canyon) for each season: winter ( $\mathrm{n}=18$, 11), spring $(n=14,10)$, summer $(n=13,14)$ and fall $(n=16,13)$. Significant values are shown in bold ( $p<0.025$ based on a Benjamini-Hochberg correction)

\begin{tabular}{|c|c|c|c|c|c|c|}
\hline Site & Ecotype & Community/group & \multicolumn{2}{|c|}{ Comparison } & $\mathrm{p}$ & $Z$ \\
\hline \multirow[t]{6}{*}{$\mathrm{CE}$} & \multirow[t]{6}{*}{ Resident } & \multirow[t]{6}{*}{ Southern } & Winter & Spring & 0.0334 & -2.1276 \\
\hline & & & & Summer & 0.3365 & 0.5816 \\
\hline & & & & Fall & 0.3667 & 0.692 \\
\hline & & & Spring & Summer & 0.0074 & 2.8112 \\
\hline & & & & Fall & 0.0118 & 2.884 \\
\hline & & & Summer & Fall & 0.4492 & 0.1276 \\
\hline \multirow[t]{6}{*}{ QC } & \multirow{6}{*}{ Transient } & \multirow[t]{6}{*}{$\mathrm{A}$} & Winter & Spring & 0.0253 & -2.389 \\
\hline & & & & Summer & 0.2509 & -0.8096 \\
\hline & & & & Fall & 0.3096 & 0.4969 \\
\hline & & & Spring & Summer & 0.1484 & 1.4453 \\
\hline & & & & Fall & 0.0157 & 2.793 \\
\hline & & & Summer & Fall & 0.1595 & 1.2464 \\
\hline
\end{tabular}

tered year-round at 2 recording sites, with higher acoustic presence at the inshore site CE. Transients were the predominant ecotype encountered at both sites, typically in spring and summer. Residents were primarily encountered at site CE in the spring, and we found evidence of possible seasonal segregation of the 2 resident communities. Offshores were encountered more often at site QC and showed no clear seasonal pattern.

\section{Transient dialect groups}

We propose a modification to the nomenclature used for distinguishing between different transient groups based on the documented group B (Wilcoxon rank sum: $\mathrm{n}=5$, rank sum $=17.5$, $\mathrm{p}=0.04)$. At site $\mathrm{QC}$, dialect group A was the most common $(26.1 \%$ of days), followed by group B $(17.4 \%)$ and group D $(11.6 \%)$. At site CE, dialect group D was the most common $(21.8 \%)$, followed by group B (20.4\%) and group A (16.3\%). Dialect group A also had a significantly higher number of days with encounters in the spring than the fall at site QC (Dunn's test: $Z=2.79, \mathrm{p}=0.016$; Table 3, Fig. 8A).

\section{DISCUSSION}

We used long-term recordings to describe the spatial and temporal occurrence of killer whales off the Washington outer coast. Killer whales were encoun- dialect variation. We offer a revised, call repertoirebased naming convention for WCTs. Since transients in the WCT population have been sighted throughout their range, we used acoustic dialects to distinguish between transient groups instead of sighting location. Based on the transient call types that have been recorded to date, it is clear that multiple dialects exist within the WCT population. Dialect groups A and B share most call types, but the main difference is the use of call types WCT03 and WCT07 by group A, whereas group B produces call type WCT04 (Table 1). Dialect group C shares some call types with groups $\mathrm{A}$ and $\mathrm{B}$, but also produces many unique call types. One of these unique call types, WCT12i, has only previously been recorded off California and was not seen in our data when other 


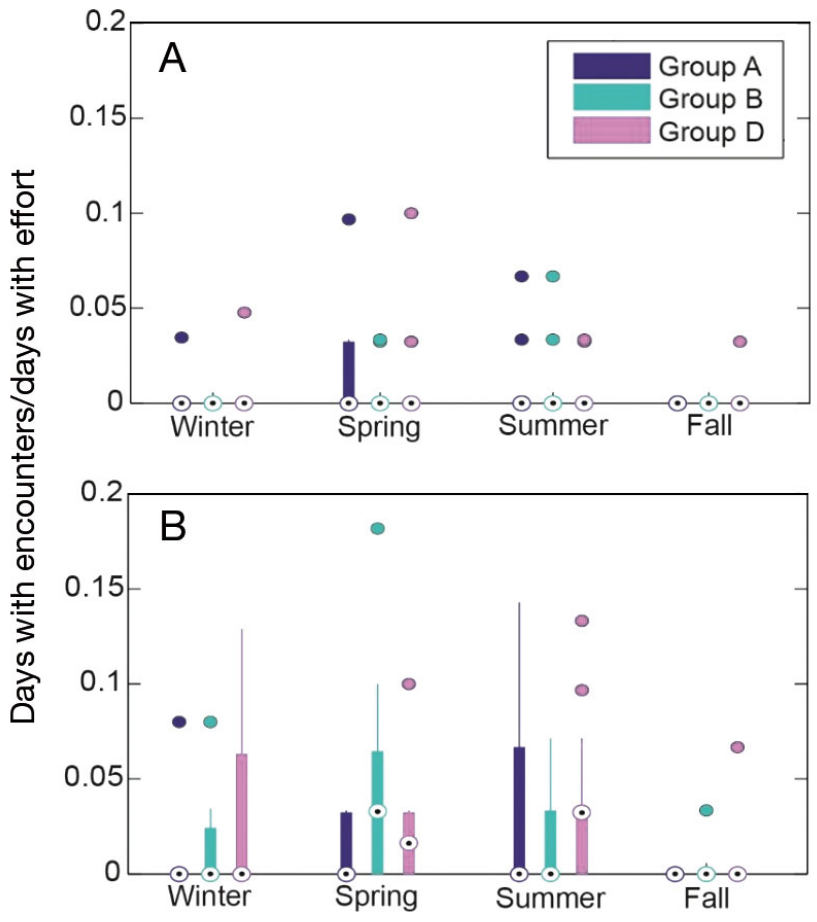

Fig. 8. Proportion of days with killer whale Orcinus orca acoustic encounters, standardized for effort, for each season at (A) Quinault Canyon and (B) Cape Elizabeth for each of the transient dialect groups. Box plot details as in Fig. 5

dialect group $C$ call types were recorded. Instead, the WCT12ii call type was recorded with other dialect group C call types. To date, the WCT12ii call type has been recorded from California (Deecke 2003) to Haida Gwaii, Canada (J. Ford unpubl. data). The exclusive use of WCT12ii off Washington instead of WCT12i suggests that many of the call types found in dialect group C may actually also be present in a distinct dialect group (group D). The division of dialect groups used in this paper is preliminary. Further analysis of transient call types should be conducted to examine finer differences within call types and further adjust dialect group classification.

Additionally, the distinction between the WCT12i and WCT12ii call types, resulting from exclusive WCT12ii presence off Washington, was unexpected and highlights the fact that our knowledge of transient acoustic repertoires is still limited. It would be interesting to look at additional recordings from the entire WCT range to try to delineate these dialect groups more clearly. It could be that dialect group C is only present off California, or perhaps it is more coastal and therefore was not detected at locations used in this study. Analysis of data collected between Washington and California could shed light on potential geographic separation of transient groups.

\section{Spatial variation and prey distribution}

All ecotypes were encountered at both sites, but there was higher overall acoustic presence closer inshore, at site CE. There were more resident encounters and significantly more transient encounters at site $\mathrm{CE}$, while offshore ecotype encounters were, as expected, more common at site QC farther offshore.

Resident and transient sightings during visual surveys typically occur in shelf waters, 28 to $40 \mathrm{~km}$ from shore, a region where prey species for both ecotypes are also commonly encountered (Green et al. 1992, Calambokidis et al. 2004, Oleson et al. 2009). For residents, the higher number of encounters at site CE could be related to the distribution of Chinook salmon, their preferred prey species (Ford et al. 1998, Ford \& Ellis 2006). The majority of Chinook are caught within $40 \mathrm{~km}$ of shore, which would be a possible explanation for the low number of encounters of residents farther offshore at site QC (Healey 1983).

Transient killer whales have been observed killing and eating several species of marine mammals, including pinnipeds, delphinids, porpoises, and baleen whales (Ford et al. 1998). During the first $5 \mathrm{yr}$ of this study, visual surveys were conducted in the area to get a better idea of the distribution of all marine mammals (Oleson et al. 2009). Harbor seals Phoca vitulina, California sea lions Zalophus californianus, Steller sea lions Eumetopias jubatus, harbor porpoises Phocoena phocoena, and gray whales Eschrichtius robustus were sighted closer to shore, typically within $25 \mathrm{~km}$, while northern fur seals Callorhinus ursinus, elephant seals Mirounga angustirostris, Dall's porpoises Phocoenoides dalli, and Pacific white-sided dolphins Lagenorhynchus obliquidens were more commonly sighted farther offshore ( $>40 \mathrm{~km}$ ) (Oleson et al. 2009). Transients were the most frequently encountered ecotype at both sites, which suggests that they may be hunting the species found along the shelf as well as those found along the slope. However, the significantly higher transient presence at site CE suggests a potential preference for prey species found on the shelf.

In Monterey Bay, California, transients are highly associated with the edge of the Monterey submarine canyon (Black et al. 2002). This is an area where Dall's porpoises commonly occur, and it is a potentially advantageous location for hunting gray whale calves during spring (Black et al. 2002). The bathymetries of Monterey Bay and our study area are similarly characterized by submarine canyons, so it is possible that similar feeding strategies are used by transients in both areas. If transients are using the 
shelf edge to their advantage in some way while hunting, that could explain the higher acoustic presence closer to the edge of the shelf, at site CE, than farther out on the slope at site QC. Gray whales travel along the Washington coastline twice a year during their migration. During the fall southbound migration, gray whales typically travel farther offshore than during the spring northbound migration, when mothers with calves will often travel within a few kilometers of the coastline (Green et al. 1992). Off Washington, however, northbound gray whales will travel farther from shore than in other coastal areas due to an increase in the width of the $0-40 \mathrm{~m}$ depth zone of the continental shelf (Green et al. 1992, Calambokidis et al. 2004, Oleson et al. 2009). The offshore presence of gray whales, and potentially calves, in addition to the presence of the submarine canyon suggest that site $\mathrm{CE}$ is likely in a good location for transient killer whales to hunt, possibly explaining their higher acoustic presence there than at site QC.

Some of the differences in recorded call abundance at the 2 sites could be due to different killer whale behavioral states at these sites. For example, because transient vocal behavior is significantly associated with feeding activity (Deecke et al. 2005), the chance of recording an acoustic encounter would be higher in an area where the animals are spending a longer period for hunting and feeding. Further studies using dedicated visual observations or satellite tags are necessary to confirm behavioral states in the different habitats. Additionally, differences in acoustic presence between sites could be due to other common biases when relying on acoustic data, such as differing vocalization rates between ecotypes and instrument detection range (see the 'Biases' section below for a more detailed discussion of these issues).

\section{Temporal variation}

Killer whales were present year round off the outer coast of Washington State and were encountered during all years of the study. We found no significant interannual variation for any of the ecotypes at either site. Hanson et al. (2013) found interannual variation for the southern residents with higher detection rates in 2009 and 2011 compared with 2006-2008, possibly related, in part, to the strength of Chinook salmon runs returning to the Columbia River. However, they note that this finding might be a result of the different recorder types used during the study. Due to variations in yearly recording effort, we examined interannual differences based on a specific time period when killer whale presence was typically high for each site, while Hanson et al. (2013) calculated the number of expected detections to account for effort variation. There was no evidence of interannual variation, but we found seasonal variation for the resident and transient ecotypes. Residents were encountered mainly during the spring and transients mainly in the spring and summer. Offshores showed no significant seasonal pattern.

In addition to providing a potential explanation of spatial distribution, prey distribution can also potentially explain the seasonality of killer whale ecotypes. We detected southern residents primarily during spring at both sites (February to June at site CE and only in March, May, and June at site QC). Off the coast of Washington, spring and summer runs of Chinook salmon migrate south as they return to rivers for spawning. For Columbia River Chinook, re-entry peaks from May to August (Myers et al. 1998), which overlaps with the detection of southern residents. Farther north, Chinook typically return to the Fraser River from July to October (Groot \& Margolis 1991). If northern residents follow Chinook as they make this southward migration to the Fraser River, it could explain their presence off the outer Washington coast from July to September, particularly if they continue south to prey upon Chinook returning to the Columbia River.

Transients prey most commonly on pinnipeds and porpoises (Ford et al. 1998). At site CE, transient encounters were highest during the spring and summer. Harbor seals and Steller sea lions are sighted year round but are found closer to the shelf edges during the spring and summer (Oleson et al. 2009). California sea lions also show increased presence during the spring (Oleson et al. 2009). In Monterey Bay, transient sightings peak when prey species are most abundant and coincide with pupping/calving seasons (Ternullo \& Black 2002). Transients feed disproportionately upon the young of some prey species, likely because they are more vulnerable and easier targets (Jefferson et al. 1991). Harbor seal pupping along the northern Washington coast takes place from May to July, which coincides with the increased transient presence in the spring and summer (Zier \& Gaydos 2014). Additionally, gray whales are present during their northbound migration with calves in the spring (Green et al. 1992).

At site QC, transient presence was highest in the spring, also coinciding with prey availability at this site. Elephant seals are one of the prey species for transient killer whales that are typically found farther offshore and are present almost exclusively in late 
winter and spring (Oleson et al. 2009). Dall's porpoises are found off Washington year-round but are typically sighted around the shelf edge during the summer and farther offshore during the spring, which also coincides with the peak in transient encounters at the shelf break (Green et al. 1992).

\section{Intra-ecotype segregation}

Competition for food resources could lead to spatial and temporal segregation of killer whales. Since killer whale ecotypes in the Northeastern Pacific have distinct prey preferences, it is not expected that ecotypes would show temporal or spatial segregation for this reason, although different communities or groups within each ecotype may segregate.

The ranges of the 2 resident communities overlap, but each community is primarily found in different regions, with northern residents typically sighted from Vancouver Island to Southeast Alaska and southern residents from southern Vancouver Island to California (Ford 1987). Off Washington, we did not find any evidence for spatial segregation of these 2 resident communities between sites, as both were typically encountered at site $\mathrm{CE}$, suggesting a shared preference for the shelf waters.

Seasonal segregation of resident clans was observed in southeastern Alaska during periods of reduced prey availability (Yurk et al. 2010). Since resident communities off Washington share a preference for Chinook salmon, it is possible that these communities could also show seasonal segregation during times of reduced prey availability. We found evidence for possible seasonal segregation of resident communities off Washington, as there were no days with southern resident encounters during July to September when the majority of northern resident encounters occurred. However, these northern resident encounters occurred mostly in 2008, with a single additional encounter in August 2004. This limited sample size does not provide substantial evidence that these 2 communities exhibit seasonal segregation in this region. Additionally, there was 1 day in February 2007 at site CE when both communities were present in the same encounter. However, seasonal segregation cannot be ruled out, especially since the period of potential segregation occurs when many Chinook salmon are leaving the area to return to the Columbia River.

The 3 transient dialect groups were encountered at both sites. However, while all dialect groups were encountered more often at site $\mathrm{CE}$, the difference was significant only for group B. While this provides no evidence of spatial segregation of transient dialect groups, it does suggest that aspects of habitat preference, possibly related to prey preference, may differ between groups. Dialect group B may favor hunting around the shelf edge as was seen by transients in Monterey Bay, whereas dialect groups A and D may sometimes move farther offshore to hunt other prey species that occur during the spring. We found no evidence of seasonal segregation between the transient dialect groups. Further delineation and understanding of transient dialect groups may be necessary to better understand any potential patterns observed within this ecotype.

\section{Biases}

When using passive acoustic methods, it is always important to note that a lack of calls does not necessarily indicate a lack of presence. Killer whales do not vocalize constantly, and therefore the reported acoustic encounters are likely an underestimate of the time killer whales are present. This is especially true for transients, as they vocalize significantly less often than the other ecotypes (Barrett-Lennard et al. 1996, Deecke et al. 2005). The decreased vocal rates seen among transients are likely due to the increased cost of vocal communication when hunting marine mammals, as these prey are able to hear killer whale calls from several kilometers away (Deecke et al. $2002,2005)$. Since the HARPs were located in areas where known transient prey species occur, it is likely that transients hunt in the area and therefore do not vocalize as frequently. However, transients are known to consistently vocalize after a predation event, suggesting that acoustic detections may give a better indication of foraging success than overall presence (Deecke et al. 2005).

Some of the deployments in this study were duty cycled, meaning that it is possible killer whales vocalized when a HARP was not recording. The average duration of a killer whale encounter was $28.2 \mathrm{~min}$. There were only 2 deployments for which the recorder was off for longer than $28.2 \mathrm{~min}$ (Table 2). A low duty cycle can result in entire encounters being missed, which would also result in an underestimate of killer whale presence (Riera et al. 2013). Since duty cycling was used in earlier deployment years, it is possible that our results are an underestimate of killer whale acoustic presence during those years.

Acoustic data can also be spatially biased, since detection range will vary depending on how sound 
propagates in the environment. Source levels for northern resident pulsed calls are estimated at $152 \pm$ $5.9 \mathrm{~dB}_{\mathrm{rms}}$ re $1 \mu \mathrm{Pa} @ 1 \mathrm{~m}$, with an estimated active space of $11 \pm 4.7 \mathrm{~km}$ (Miller 2006, Holt et al. 2011). This estimate assumes a water depth of $100 \mathrm{~m}$ and, keeping all other factors constant, an increase in water depth would result in an increased detection range (Miller 2006). This detection range could be a very rough estimate for site CE ( 120 m depth) but the detection range is potentially larger for site QC ( 600-1400 m depth). However, this estimate was based on sea state 0 ambient noise levels, which are rarely encountered at these sites. Miller's (2006) estimates with sea state 6 ambient noise levels saw a $75 \%$ reduction in active space. Since we generally had more killer whale encounters at site CE, which likely had a lower detection range, the absolute difference in killer whale use between the sites is likely even larger than reported here. Likewise, this difference in detectability is also a possible reason for the larger proportion of unidentified killer whales, relative to other ecotypes, occurring at site $\mathrm{QC}$, as larger detection range, and quieter conditions at a deeper site, will result in a greater number of faint and difficult to identify calls. Improved estimates of killer whale source levels for all ecotypes are necessary to better model the detection ranges for the 2 recording sites.

Due to human error, it is possible that some calls were misclassified and encounters could have been attributed to the wrong ecotype, community, or group. However, misclassification was unlikely, due to the distinct nature of killer whale pulsed call types and the abundance of call catalogues used for comparisons. The fact that only pulsed calls were used for this analysis presents another source of bias, as no effort was made to include other types of killer whale vocalizations (whistles or echolocation clicks). Including all killer whale signal types would provide a better indication of overall presence in the area but was not possible for this study, as inter-ecotype differences in whistles and clicks are not as well understood as they are for pulsed calls.

\section{CONCLUSIONS}

Long-term passive acoustic monitoring off the outer coast of Washington provided insight into the spatial and temporal patterns of the different killer whale ecotypes that inhabit the region. Acoustic presence was higher on the shelf than on the slope for residents and transients, indicating potential habitat preference likely related to the distribution of prey species. For the offshore ecotype, more encounters occurred on the slope, as expected, due to this ecotype's observed preference for pelagic waters. Additionally, distinct seasonal patterns were found for the different ecotypes, with residents mainly present during the spring, transients present during the spring and summer, and occasional offshore presence year-round. Seasonal patterns for residents and transients fit known seasonal distribution patterns of preferred prey species, offering further insights into the foraging ecology of this apex predator. The spatial and temporal patterns observed here can be used to expand and improve critical habitat designation for this at-risk species. Additionally, the high number of transient encounters, relative to the other ecotypes, can be of use in expanding our knowledge of transient acoustics and perhaps provide insights into the social structure of the WCT population.

Acknowledgements. HARP deployment, recovery, and data processing were supported by Hannah Bassett, Chris Garsha, Ryan Griswald, Brent Hurley, John Hurwitz, Erin O'Neill, and Bruce Thayre. Analysis was supported by Marie Roch and Sean Herbert via the Tethys database, which was used to store metadata and generate figures. We thank the Cascadia Research Collective (John Calambokidis, Erin Falcone, and Greg Schorr) for visual survey data collected in 2004-2008. We also thank Simone Baumann-Pickering and Amanda Debich for assistance with initial planning and analysis and Leah Varga for her input on figures and overall manuscript preparation. We acknowledge use of the Maptool program for creation of Fig. 1; Maptool is a product of seaturtle.org. This project was funded by the Chief of Naval Operations N45 Living Marine Resources Program (Frank Stone and Ernie Young) and US Pacific Fleet (Chip Johnson), and support was also provided by the Naval Postgraduate School (Curt Collins and John Joseph). Research was conducted in the Olympic Coast National Marine Sanctuary under permits OCNMS-2006-003-(A1, A2, A3) and OCNMS-2010-010(A1), and we thank Mary Sue Brancato and Liam Antrim for their assistance.

\section{LITERATURE CITED}

Barrett-Lennard L (2000) Population structure and mating patterns of killer whales as revealed by DNA analysis. PhD Thesis, University of British Columbia, Vancouver, British Columbia

* Barrett-Lennard LG, Ford JKB, Heise KA (1996) The mixed blessing of echolocation: differences in sonar use by fisheating and mammal-eating killer whales. J Anim Behav 51:553-565

Bigg MA, Olesiuk PF, Ellis GM, Ford JKB, Balcomb KC (1990) Social organization and genealogy of resident killer whales (Orcinus orca) in the coastal waters of British Columbia and Washington State. Rep Int Whal Comm Spec Issue 12:383-405

Black N, Ternullo R, Schulman-Janiger A, Ellis G, Dahlheim M, Stap P (2002) Behavior and ecology of killer whales in 
Monterey Bay, California. Fourth International Orca Symposium and Workshops. CEDC-CNRS, Chizé, p 40-44

Calambokidis J, Steiger GH, Ellifrit DK, Troutman BL, Bowlby CE (2004) Distribution and abundance of humpback whales (Megaptera novaeangliae) and other marine mammals off the northern Washington coast. Fish Bull 102:563-580

Dahlheim ME, Schulman-Janiger A, Black N, Ternullo $\mathrm{R}_{r}$ Ellifrit D, Balcomb KC (2008) Eastern temperate North Pacific offshore killer whales (Orcinus orca): occurrence, movements, and insights into feeding ecology. Mar Mamm Sci 24:719-729

Deecke VB (2003) The vocal behaviour of mammal-eating killer whales: communicating with costly calls. $\mathrm{PhD}$ thesis, University of St. Andrews

Deecke VB, Slater PJB, Ford JKB (2002) Selective habituation shapes acoustic predator recognition in harbour seals. Nature 420:171-173

Deecke VB, Ford JKB, Slater PJB (2005) The vocal behaviour of mammal-eating killer whales: communicating with costly calls. Anim Behav 69:395-405

Erbe C (2002) Underwater noise of whale-watching boats and potential effects on killer whales (Orcinus orca), based on an acoustic impact model. Mar Mamm Sci 18:394-418

Ford JKB (1987) A catalogue of underwater calls produced by killer whales (Orcinus orca) in British Columbia. Can Data Rep Fish Aquat Sci 633:1-165

Ford JKB (1989) Acoustic behaviour of resident killer whales (Orcinus orca) off Vancouver Island, British Columbia. Can J Zool 67:727-745

Ford JKB (1991) Vocal traditions among resident killer whales (Orcinus orca) in coastal waters of British Columbia. Can J Zool 69:1454-1483

Ford JKB, Ellis GM (2006) Selective foraging by fish-eating killer whales Orcinus orca in British Columbia. Mar Ecol Prog Ser 316:185-199

Ford JKB, Ellis GM, Barrett-Lennard LG, Morton AB, Palm RS, Balcomb KC (1998) Dietary specialization in two sympatric populations of killer whales (Orcinus orca) in coastal British Columbia and adjacent waters. Can J Zool 76:1456-1471

Ford JKB, Ellis GM, Olesiuk PF, Balcomb KC (2010) Linking killer whale survival and prey abundance: food limitation in the ocean's apex predator? Biol Lett 6:139-142

Ford JKB, Ellis GM, Matkin CO, Wetklo MH, BarrettLennard LG, Withler RE (2011) Shark predation and tooth wear in a population of northeastern Pacific killer whales. Aquat Biol 11:213-224

Goley PD, Straley JM (1994) Attack on gray whales (Eschrichtius robustus) in Monterey Bay, California, by killer whales (Orcinus orca) previously identified in Glacier Bay, Alaska. Can J Zool 72:1528-1530

Green GA, Brueggman JJ, Grotefendt RA, Bowlby CE, Bonnell ML, Balcomb KC (1992) Cetacean distribution and abundance off Oregon and Washington, 1989-1990. In: Brueggeman JJ (ed) Oregon and Washington marine mammal and seabird surveys. Ebasco Environmental, Bellevue, WA, p 1-100

Groot C, Margolis L (1991) Pacific salmon life histories. University of British Columbia Press, Vancouver, BC

Hanson MB, Noren DP, Norris NF, Emmons CA, Guy T, Zamon J (2008a) Pacific Ocean killer whale and other marine mammals distribution survey, March 2006 (PODs 2006) conducted aboard the NOAA ship McArthur II. NWFSC, Seattle, WA
Hanson MB, Noren DP, Norris TF, Emmons CA, Holt MM, Guy T, Zamon J (2008b) Pacific Ocean killer whale and other cetaceans distributions survey, May 2007 (PODs 2007) conducted aboard the NOAA ship McArthur II. NWFSC, Seattle, WA

Hanson MB, Noren DP, Norris TF, Emmons CA, Holt MM, Phillips E, Zamon J (2009) Pacific orca distribution survey (PODs) conducted aboard the NOAA ship McArthur II in March 2008. NWFSC, Seattle, WA

Hanson MB, Noren DP, Norris TF, Emmons CA and others (2010) Pacific orca distribution survey (PODS) conducted aboard the NOAA ship McArthur II in March-April 2009. NWFSC, Seattle, WA

Hanson MB, Emmons CK, Ward EJ, Nystuen JA, Lammers MO (2013) Assessing the coastal occurrence of endangered killer whales using autonomous passive acoustic recorders. J Acoust Soc Am 134:3486-3495

Healey MC (1983) Coastwide distribution and ocean migration patterns of stream- and ocean-type Chinook salmon, Oncorhynchus tshawytscha. Can Field Nat 97:427-434

*Hoelzel AR, Dahlheim M, Stern SJ (1998) Low genetic variation among killer whales (Orcinus orca) in the eastern North Pacific and genetic differentiation between foraging specialists. J Hered 89:121-128

Holt MM, Noren DP, Emmons CK (2011) Effects of noise levels and call types on the source levels of killer whale calls. J Acoust Soc Am 130:3100-3106

Jefferson TA, Stacey PJ, Baird RW (1991) A review of killer whale interactions with other marine mammals: predation to coexistence. Mammal Rev 21:151-180

Miller PJO (2006) Diversity in sound pressure levels and estimated active space of resident killer whale vocalizations. J Comp Physiol A Neuroethol Sens Neural Behav Physiol 192:449-459

Myers JM, Kope RG, Bryant GJ, Teel D and others (1998) Status review of Chinook salmon from Washington, Idaho, Oregon, and California. Tech Memo NMFS-NWFSC-35. US Department of Commerce, NOAA, Silver Spring, MD

*Nehlsen W, Williams JE, Lichatowich JA (1991) Pacific salmon at the crossroads: stocks at risk from California, Oregon, Idaho and Washington. Fisheries 16:4-21

Oleson EM, Calambokidis J, Falcone E, Schorr G, Hildebrand JA (2009) Acoustic and visual monitoring of cetaceans along the outer Washington coast. Report NPSOC-09-001. Naval Postgraduate School, Monterey, CA

Oleson EM, Calambokidis J, Falcone E, Schorr G, Douglas A (2012) Visual monitoring for marine mammals off Washington. Report NPS-OC-12-001CR. Naval Postgraduate School, Monterey, CA

Rayne S, Jkonomou MG, Ross PS, Ellis GM, Barrett-Lennard LG (2004) PBDEs, PBBs, and PCNs in three communities of free-ranging killer whales (Orcinus orca) from the northeastern Pacific ocean. Environ Sci Technol 38: 4293-4299

Riera A (2012) Patterns of seasonal occurrence of sympatric killer whale lineages in waters off Southern Vancouver Island and Washington State, as determined by passive acoustic monitoring. MSc thesis, University of Victoria, Victoria, BC

* Riera A, Ford JKB, Chapman NR (2013) Effects of different analysis techniques and recording duty cycles on passive acoustic monitoring of killer whales. J Acoust Soc Am 134:2393-2404

Ross PS, Ellis GM, Jkonomou MG, Barrett-Lennard LG, Addison RF (2000) High PCB concentrations in free-ranging 
killer whales, Orcinus orca: effects of age, sex and dietary preference. Mar Pollut Bull 40:504-515

Samarra FIP, Deecke VB, Vinding K, Rasmussen MH, Swift RJ, Miller PJO (2010) Killer whales (Orcinus orca) produce ultrasonic whistles. J Acoust Soc Am 128: EL205-EL210

Simonis AE, Baumann-Pickering S, Oleson EM, Melcon ML, Gassman M, Wiggins SM, Hildebrand JA (2012) Highfrequency modulated signals of killer whales (Orcinus orca) in the North Pacific. J Acoust Soc Am 131: EL295-EL301

Ternullo R, Black N (2002) Predation behavior of transient killer whales in Monterey Bay, California. Fourth International Orca Symposium and Workshops. CEDCCNRS, Chizé, p 156-159

Thomsen F, Franck D, Ford JKB (2001) Characteristics of whistles from the acoustic repertoire of resident killer

Editorial responsibility: Peter Corkeron,

Woods Hole, Massachusetts, USA whales (Orcinus orca) off Vancouver Island, British Columbia. J Acoust Soc Am 109:1240-1246

Wiggins SM, Hildebrand JA (2007) High-frequency acoustic recording package (HARP) for broadband, long-term marine mammal monitoring. International Symposium on Underwater Technology 2007 and International Workshop on Scientific Use of Submarine Cables and Related Technologies 2007. Institute of Electrical and Electronics Engineers, Tokyo

Yurk H, Filatova O, Matkin CO, Barrett-Lennard LG, Brittain M (2010) Sequential habitat use by two resident killer whale (Orcinus orca) clans in Resurrection Bay, Alaska, as determined by remote acoustic monitoring. Aquat Mamm 36:67-78

Zier JC, Gaydos JK (2014) Harbor seal species profile. In: Gaydos JK (ed) Encyclopedia of Puget Sound. SeaDoc Society, Eastsound, WA, p 1-55

Submitted: December 1, 2016; Accepted: April 12, 2017 Proofs received from author(s): May 19, 2017 